\title{
Translation Techniques of Sentences Accommodating Satirical Language Styles in The Historical Novels Bumi Manusia and Anak Semua Bangsa
}

Noviana Murdiyati ${ }^{1 *}$, M.R. Nababan² \& Djatmika ${ }^{3}$

${ }^{123}$ Master of Linguistic, Faculty of Cultural Science, Sebelas Maret University, Indonesia

Corresponding Author: Noviana Murdiyati, E-mail: novianamurdiyati@student.uns.ac.id

\section{ARTICLE INFORMATION}

Received: November 18, 2020

Accepted: January 14, 2021

Volume: 4

Issue: 1

DOI: 10.32996/ijllt.2021.4.1.10

\section{KEYWORDS}

Satirical language styles, Translation technique, Historical novel

\section{ABSTRACT}

The purpose of the research is to identify the translation techniques used in translating satirical language style in historical novels Bumi Manusia and Anak Semua Bangsa. This research is an embedded research with a descriptive qualitative approach conducted on the romance Bumi Manusia and Anak Semua Bangsa. Data were collected through content analysis and validated by rater through focus group discussions (FGD). The results show that there were 183 satirical language style data in historical novels Bumi Manusia and Anak Semua Bangsa which used 16 translations techniques namely established equivalence, explicitation, modulation, paraphrase, implicitation, compensation, pure borrowing, variant borrowing, transposition, addition, reduction, generalization, literal, discursive creation, particularization and neutralization.

\section{Introduction}

Nababan (2008) state that the translator is a facilitator who bridges two parties who have different languages so that they can communicate well (p. 4). In the current era of globalization, the need for the services of a translator is increasing day by day, especially for the translation of literature.

This study used historical novels, a type of literature as a translation study. Historical-themed novel usually take a time setting in the past, where a certain event occurred. Historical novels bring the reader to the past. They are invited to explore and understand the events, mindset and actions of people in the past. Because of that, many historical novels have begun to be translated.

Badudu explained that historical novels are a type of novel that depicts the lives of story characters in a historical period. There are historical novels that only focus on the depiction of historical elements and events, and there are also historical novels that emphasize the main character taken from a historical figure, with the author's imagination telling the character's life experiences, such as attitudes, dreams, life struggles, and stories of characters in a historical period (Badudu, 1977, pp. 42-45) 7: 42-45).

Each writer has a different and distinctive language style that distinguishes one writer from another. According to Keraf (2009) language style is a way to express oneself, through language, behavior, dress and so on. Language style allows us to judge a person's personality, character, and ability to use the language (p. 113).

This research focuses on the translation techniques in translating satirical language styles which include irony, cynicism, sarcasm, satire, and innuendo found in the historical novel Bumi Manusia and Anak Semua Bangsa and its translations The Earth of Man Kind and Children of All Nations.

\section{Literature Review}

\section{Satirical Language Styles}

Satirical language style is a group of language styles that express intent or ideas in a satirical way to increase the impression and meaning of words to readers and interlocutors. The satirical language style is used by someone to express ideas and feelings, both in oral and written form which are influenced by personal context and the surrounding environment, accompanied by behavior, and how to dress. There are five types of satirical language style described by Keraf (2009, pp. 143-144), namely:

Irony

K C AL-KINDI CENTER R D FOR RESEARCH AND DEVELOPMENT Your gateway to world-class research

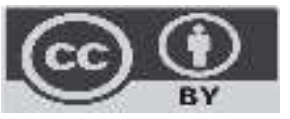

Published by Al-Kindi Center for Research and Development. Copyright (c) the author(s). This open access article is distributed under a Creative Commons Attribution (CC-BY) 4.0 license 
According to Keraf (2009) irony is a reference to say something with a different meaning or purpose from what is contained in a series of words (p. 143). In line with Aminuddin (2013), he defines irony as a language style that contains hidden meaning in an explicit way (p. 246). It means that the hidden meaning is conveyed through things that are clearly different and even the opposite of the actual meaning. Irony will work if the interlocutor or listener is also aware of the hidden meaning behind the series of words.

\section{Cynicism}

Cynicism is an insinuation that contains ridicule that is harsher than irony. Keraf (2009) defines cynicism as an insinuation in the form of doubt that contains ridicule of sincerity (p. 143). Cynicism is usually used to express insinuation harshly and is generally used to criticize or ridicule something in the form of an idea, purpose or plan.

\section{Sarcasm}

Keraf (2009) defines sarcasm as a harsher reference to irony and cynicism. Sarcasm is used to express insinuations directly with harsh words (pp. 143-144).

\section{Satire}

Keraf (2009) defines satire as an expression to laugh at or reject something. Satire is used to express insinuation a classy way, usually used by writers and poets to convey criticism (p. 144).

\section{Innuendo}

Keraf (2009) defines innuendo as an insinuation that belittles the actual reality, expresses criticism with indirect suggestions and often seems painless when seen casually (p.144). Innuendo is used to express insinuation by making a problem small or trivial.

\section{Translation}

Translation is a process of transferring ideas or messages from one language to another. Several translation experts provide clear definitions of translation. Catford (1978) defines translation as "... the replacement of textual material in one language (SL) by equivalent textual material in another language (TL)" (p. 20). Catford's definition explains that translation is the re-placement of a text in the source language into the target language text. Text in the source language is placed back into the target language and must remain equivalent. So, according to Catford, in translation, a translator must be able to replace or put back a source language text material to an equivalent target language.

Meanwhile, Larson (1998) stated that "translation consists of transferring the meaning of the source language into receptor language" (p. 3). In other words, Larson defines translation as the process of transferring meaning from the source language to the target language.

This is in line with Nida's opinion (1969), which states that "Translation consists of reproducing in the receptor language, the closest natural equivalence of the source language message, first in terms of meaning and secondly in terms of style" ( $p$. 12). According to Nida, translation is to reproduce the natural equivalent and closest to the message in the source language, which is related to meaning, then related to style. In this definition, the meaning and style of the source language must be conveyed appropriately in the target language.

\section{Translation Techniques}

Translation technique is a method used to transfer messages from the source language to the target language, applied at the level of words, phrases, clauses and sentences. Molina and Albir (2002) define translation techniques as a procedure used to analyze and classify a translation equivalent or not between the source text and the target text (p. 509). Molina and Albir (2002) classify the types of translation techniques into 18 techniques (p. 509). Following are explanations for 18 translation techniques adapted from Molina and Albir.

Adaptation is a translation technique that replaces cultural elements contained in the source language to make it more acceptable in the target language. This technique can be used if the cultural elements or elements have an equivalent in the target language.

Amplification is a technique that provides details of terms that are not contained in the target language, namely by adding information, or explicit paraphrase. Amplification consists of four technical categories, namely addition, paraphrase, annotation, and explicitation. Addition is a translation technique that provides additional information from a foreign term in the source 
language. Then, paraphrase is a translation technique that conveys the source language message into the target language but is conveyed in a different but still equal way. Finally, annotation is a translation technique that provides additional information about a term that is placed in the footnote of a translated text.

Borrowing is a translation technique that uses words or expressions directly from the source language in the target language. It can be pure borrowing, that is, borrowing without making any changes and can be natural borrowing, in which words in the source language are adjusted to the spelling of the target language.

Calque is a technique of literally translating a word or phrase from the source language to the target language using the equivalent word in the target language. This translation technique is similar to literal translation, but the difference is seen in the source language structure which still appears in the target language or maintains the lexical but still follows the structure of the target language.

Compensation is a translation technique that changes the position of the source language elements from a certain place and unit to another place and unit in the target language. This is done because the stylistic effect on the source language cannot be applied to the target language.

Description is a translation technique that replaces the term in the source language with its description in the target language. It used when the terms in the source language do not have an equivalent in the target language.

Discursive Creation is a translation technique that displays a temporary equivalent that is different from the original context. This is done to attract the reader's attention. This technique often appears in the translation of film, book or novel titles.

Established equivalence is a translation technique that translates terms in the source language with terms that are recognized in the target language. The terms in the source language are generally based on dictionaries or colloquial expressions.

Generalization is a translation technique that uses more general terms and is known to the wider community. This translation technique is carried out when the term in the source language refers to a specific part, while the equivalent in the target language does not have the same specific equivalent.

Linguistic amplification is a translation technique that adds a linguistic element to the text in the target language. The linguistic element was added not to add the message but to further clarify the message conveyed. This technique is often used in consecutive interpreting and dubbing.

Linguistic compression is a translation technique that is carried out by synthesizing or gathering linguistic elements that reduce the linguistic elements of the target language. This is the opposite of the linguistic amplification technique. It is commonly used in simultaneous interpretation and subtitling.

Literal Translation is a translation technique that translates word for word by paying attention to the structure of the target language, but does not relate it to the context.

Modulation is a translation technique that changes the point of view, focus or cognitive aspects of the source language, both from a structural and lexical perspective.

Particularization is a translation technique that uses more specific and concrete terms. This technique is the opposite of the generalization technique which translates from general things to specific things.

Reduction is a translation technique that compresses the elements of information in the target language but does not eliminate or change the messages in the source language.

Substitution is a translation technique that replaces linguistic elements with paralinguistic (such as intonation and gestures) and vice versa. 
Transposition is a translation technique that replaces the grammatical category of the source language with the target language, for example changing words into phrases. This technique is usually used because of the differences in grammar between the source language and the target language.

Variation is a translation technique that replaces linguistic or paralinguistic elements (intonation, gesture) that affect aspects of linguistic diversity such as language style, dialect, etc.

\section{Methodology}

This research is an embedded research with a descriptive qualitative approach. The location of this research is novel by Pramoedya Ananta Toer, namely the eleventh printed Bumi Manusia in 2011 and the sixth edition of Anak Semua Bangsa in 2002. Both novels were translated by Max Lane under the titles The Earth of Man Kind and Child of Al Nations respectively which were published in 1996. The data in this study were divided into two types of data, namely primary data and secondary data. Primary data is linguistic data, namely sentences that accommodate satirical language styles and secondary data namely novel reviews, publication texts, and theories relevant to language style analysis. This study used two data collection techniques, namely document analysis and focus group discussion (FGD).

\section{Results and Discussion}

From the analysis, it was found that 16 translation techniques were applied in the satirical language translation in the historical novels Bumi Manusia (This Earth of Man Kind) and Anak Semua Bangsa (Children of All Nations). In analyzing the satirical language style, this study uses the theory proposed by Keraf (2009, pp. 143-144) and to identify translation techniques using theory by Molina \& Albir (2002, p. 509). Translation techniques can be seen in the table below.

Table 1. Translation Techniques of Satirical Language Style in Historical Novels Bumi Manusia (This Earth of Man Kind) and Anak Semua Bangsa (Children of All Nations)

\begin{tabular}{|c|c|c|c|}
\hline No. & Translation Technique & $\Sigma$ & Percentage \\
\hline 1. & Established Equivalence & 893 & $73,2 \%$ \\
\hline 2. & Explicitation & 121 & $9,9 \%$ \\
\hline 3. & Modulation & 57 & $4,7 \%$ \\
\hline 4. & Paraphrase & 36 & $2,9 \%$ \\
\hline 5. & Implicitation & 29 & $2,4 \%$ \\
\hline 6. & Compensation & 19 & $1,6 \%$ \\
\hline 7. & Pure Borrowing & 14 & $1,1 \%$ \\
\hline 8. & Variant Borrowing & 13 & $1 \%$ \\
\hline 9. & Transposition & 12 & $0,9 \%$ \\
\hline 10. & Addition & 6 & $0,5 \%$ \\
\hline 11. & Reduction & 6 & $0,5 \%$ \\
\hline 12. & Generalisation & 4 & $0,3 \%$ \\
\hline 13. & Literal & 4 & $0,3 \%$ \\
\hline 14. & Discursive Creation & 3 & $0,24 \%$ \\
\hline 15. & Particularisation & 2 & $0,16 \%$ \\
\hline 16. & Neutralisation & 1 & $0,08 \%$ \\
\hline \multicolumn{2}{|l|}{ Total } & 1220 & $100 \%$ \\
\hline
\end{tabular}




\section{Established Equivalence}

Example:

SL : "Apa guna jadi Jawa kalau hanya untuk dilanggar hak-haknya?"

TL : "What's the use of being Javanese only to have one 's rights violated?"

Example of the data above is a sentence that accommodates the satirical style spoken by Minke to his brother who opened his diary without permission. Instead of apologizing, he blamed Minke because he is considered no longer behaving as a Javanese. The translator uses established equivalence techniques to translate the expression by using words or terms that are often used.

\section{Explicitation}

Example:

SL : "Kalau suka, kau boleh ikuti contoh abangmu."

TL : "If you like, you may follow your brother's example."

The example above is a sentences that accommodate cynicism. Explicitation techniques used to translate 'if you like' to emphasize Nyai Ontosoroh's insinuation on his son which she tells to Annelies if she follows her brother's bad behavior, she will suffer the same fate as her brother.

\section{Modulation}

Example:

SL : Begitu macamnya peradaban Eropa yang kau ajarkan padaku berbelas tahun? Kau agungkan setinggi langit?

$\mathrm{TL}$ : So this is the European civilization about which you've been teaching me all these years? You've been glorifying to the heavens?

In example above, phrase 'all these years?' is translated using modulation technique. The use of this technique only changes the point of view, but does not change the meaning of the message conveyed in the target language. The use of this technique also did not cause a shift in the ironic style conveyed by Nyai Ontosoroh to her husband regarding the teachings of European culture which she has been honoring so far, but in fact what was taught did not match the reality.

\section{Paraphrase}

Example:

SL : Tak ada kudengar orang bertepuk lagi sebagai pernyataan suka. Hanya karena yang terpanggil anak Pribumi.

$\mathrm{TL}$ : There was no more applause supporting me, only because the person called up was a native.

The example data above is a sentence that accommodates the innuendo language style spoken by Minke. There are different concepts in the source language and target language but the meaning of the message remains unchanged, namely that no one appreciates Minke's achievement as the best student by giving applause just because he is a Native.

\section{Implicitation}

Example:

SL : "Nampaknya senang pula? Karena ada Annelies?"

TL : "It seems you like it here too. Because of Annelies?"

The example above is a sentence that accommodates the cynicism style uttered by Robert Mellema to Minke to insult Minke because he likes his sister. The translator implies the message in the source language through the word "because" but does not change the cynicism style in the target language.

\section{Compensation}

Example:

SL : Mereka membanting tulang di seluruh dunia untuk mengumpulkan kekayaan melulu.

$\mathrm{TL}$ : They broke their backs all over the world for no other purpose than to accumulate wealth.

The example above is the compensation technique for sarcasm applied to the word 'melulu', whose position at the end of a sentence in source language is translated as 'for no other purpose than' and the position changes in the middle of the sentence in the target language. The phrase was uttered by Khow Ah Soe, a man from China who insinuated his fellow countrymen who had wandered just to gather material.

\section{Pure Borrowing}

Example:

SL : Kalah aku olehmu, Minke, seorang Pribumi saja - siswa H.B.S.

TL : I'm outdone by you, Minke, you, just a Native - an H.B.S. student. 
The data example above is pure borrowing technique in sentences that accommodate ironic style applied to the word 'Minke' which refers to a person's name. This phrase was uttered by Robert Mellema, a Dutch descent to Minke who is a native with the aim of mocking him.

\section{Variant Borrowing}

Example:

$\mathrm{SL}$ : "Sedang Tuan pun masih berthau-chang."

$\mathrm{TL}$ : "Yet you yourself still wear the thau-cang."

The example above is the variant borrowing technique in a sentence that accommodates a cynicism style applied to the word 'berthau-chang' which is a loan word from Chinese which means pigtail. The sentence was uttered by a Dutch magazine editor to insult the Chinese writer with the intention of mocking him.

\section{Transposition}

Example:

SL : Jadi seperti segolongan sebangsaku, pikirku, bangsa jawa, yang menganggap dirinya paling sopan, paling beradab, paling luhur.

TL : So they were like my own people, I thought, the Javanese, who looked upon themselves as the most polite, most civilized, and most noble of all people.

The translator uses a transposition translation technique in a sentence that accommodates the satirical style of the word "pikirku" which in the source language is a passive verb translated into "I thought" in the target language and turns into an active verb. This phrase was uttered by Minke to insult his people who thought that his group was the best when in fact it was not.

Addition

Example:

SL : Bagaimana bisa sebuah Pengadilan Putih pula, dengan orang-orang yang sangat, sangat terpelajar dan berpengalaman mengurusi keadilan, bisa bekerja memperlakukan hukum yang begitu berlawanan dengan perasaan hukum kami?

TL : How can a court, and a European court too, manned by very educated people, experienced in matters of justice, with the degree of Bachelor of Laws, carry out the law this way, so opposed to our sense of law?

In the example above the translator uses addition techniques in sentences that accommodate cynicism style. Minke uttered that sentence to insult the Amsterdam court in Java. The translator adds the information "with the degree of Bachelor of Laws" in the target language to emphasize the cynicism style statement in the source language regarding people who work in court, especially with a law degree, not using the law properly.

\section{Reduction}

Example:

SL : Bagi mereka Pribumi mesti salah, orang Eropa harus bersih, jadi Pribumi pun sudah salah.

$\mathrm{TL}$ : Natives must always be in the wrong, Europeans must be innocent, so therefore Natives must be wrong to start with. In this example, the translator uses reduction technique in sentences that accommodate the irony style spoken by Nyai Ontosoroh to Minke to insult the attitude of the invaders. This technique applied by removing the word "Bagi mereka" that means "for them" in the target language to compress the information.

\section{Generalization}

Example:

SL : Lihat Belanda buntung pincang dengan anaknya itu!

$\mathrm{TL}$ : Look at the lame, stumped foreigner and his child!

The example above is an expression of the sarcasm style spoken by residents when they saw the lame Jean Marais. The word 'Dutch' which refers to a nation's name is translated into 'foreigner' with a more general meaning because Jean is actually French. However the society considers all foreigners who come to their place to be Dutch.

\section{Literal}

Example:

SL : Perempuan tahu apa? Duniamu cuma klungsu.

TL: What does a woman know? Your world is no more than the tamarind seed. 
In the example above, the word "klungsu" is translated into "tamarind seed" in the target language using literal techniques in the translation process. This expression was an innuendo style uttered by Sastro Kassier to his wife because he was annoyed that his wife kept demanding him to cancel the agreement with his boss to make their daughter a concubine. Sastro Kassier said that his wife did not know anything and compared his wife's world as small as klungsu (the name for tamarind seeds).

\section{Discursive Creation}

Example:

SL : Yang terpelajar justru kekejiannya.

$\mathrm{TL}$ : The more educated the person, the more educated the deviousness.

In this example, the translator uses a discursive creation technique. The translator uses a discursive creation technique that is completely different from the source language. This is done to attract the reader's attention by introducing various other creations in the translation results. This expression is an irony uttered by Nyai Ontosoroh when she teased Ir. Mellema, someone who is educated but wants to take the company away from her.

\section{Particularization}

Example:

SL : Annelies, anakku, Tuan, hanya seorang Indo, maka tidak boleh melakukan apa yang dilakukan bapaknya?

TL: Annelies, my daughter, Sirs, is only an Indo, so is that why she may not do the things her father did?

In this example, the translator uses particularization technique to translate the word "anakku" to "my daughter". In source language, the word "anakku" is still general, it does not indicate the gender of the child. The translator uses particularization technique by replacing "my daughter" in the target language which indicates the gender of the child. In the sentence above, Nyai Ontosoroh uttered a cynicism style of language to the judge who did not approve of Annelies' marriage to Minke.

\section{Neutralization}

\section{Example:}

SL: "Kowe kira, kalo sudah pake pakean Eropa, bersama orang Eropa, bisa sedikit bicara Belanda, lantas jadi Eropa? Tetap monyet!"

TL: "You think, boy, because you wear European clothes, mix with Europeans, and can speak a little Dutch you then become a European? You're still a monkey. "

In Javanese, the pronoun 'kowe' is a pronoun that refers to a person who is younger or has a lower social status. In the context of the sentence above, the style of sarcasm was conveyed by Herman Mellema to Minke. The use of the pronoun 'kowe' was deliberately done by Herman Mellema to call Minke because he considered Minke, a native, a person of a lower rank than him.

\section{Conclusion}

The purpose of the research is to identify the translation techniques used in translating satirical language style in historical novels Bumi Manusia and Anak Semua Bangsa. Based on the results of the research, there were 183 data from both novels, which consisted of 5 types of satirical language styles. Besides, 16 translation techniques were found in translating sentences accommodating satirical language styles. The most frequently used translation technique is the established equivalence, which shows that the translator wants to convey the message as accurately as possible by using the terms commonly used in the target language. Several translation techniques produce good translations, namely established equivalents, explicitation, modulation, paraphrase, implicitation, compensation, transposition, addition, generalization, particularization, and neutralization. Meanwhile, pure borrowing and variant borrowing in cultural terms will affect the translation results to be less acceptable to the reader because they still use cultural terms from the source language that are not understood by the target language readers. Literal translation and discursive creations cause the translation results to be out of context. Finally, reduction results in an inaccurate translation because it removes some parts of the message that are translated into the target language. It is important for the translator to consider the technique used in translating because it determine the quality of translation result. For the next research, the researcher can carry the same theme by examining deeper material about the function of satirical language style to improve the previous research.

Funding: This research received no external funding

Acknowledgments: This paper and the research behind would not have been possible without the exceptional support of my supervisor, M.R. Nababan and Djatmika. Their enthusiasm, knowledge and exacting attention to detail have been an inspiration and kept my work on track.

Conflicts of Interest: The authors declare no conflict of interest. 


\section{References}

[1] Aminuddin. (2013). Pengantar Apresiasi Karya Sastra. Bandung: Sinar Baru Algesindo.

[2] Arifiyani, Nurul \& Hartati, Umi. (2015). Gaya Bahasa Sindiran dan Perbandingan pada Status Twitter Sujiwo Tejo. CARAKA Volume 1 No. 2 Edisi Juni 2015

[3]Badudu, J.S. (1977). Sari Kesusastraan Indonesia. Pustaka Prima

[4] Catford, J.C. (1978). A Linguistic Theory of Translation: An essay in Applied Linguistics. Oxford University Press.

[5] Dinari, Irene, Nababan, M.R \& Djatmika. (2017). The Analysis of Translation Techniques of Irony and Sarcasm in Novel Entitled The Return of Sherlock Holmes. Prasasti: Journal of Linguistics 2(1), 69-88.

[6] Heru, Agus. (2018). Gaya Bahasa Sindiran ironi, Sinisme dan Sarkasme dalam Berita Utama Harian Kompas. PEMBAHSI Jurnal Pembelajaran Bahasa dan Sastra Indonesia, 8(2) Tahun

[7] Keraf, Gorys. (2009). Diksi dan Gaya Bahasa. PT Gramedia Pustaka Utama.

[8] Larson, Mildred. L. (1998). Meaning-Based Translation. University Press of America.

[9] Molina, L \& Albir, A.H. (2002). Translation Technique Revisited: A Dynamic and Functionalist Approach. Journal Meta Vol. XLVII, No.4

[10] Nababan, M.R. (2008). Kompetensi Penerjemahan dan Dampaknya pada Kualitas Terjemahan. Universitas Sebelas Maret.

[11] Nida, E. A., \& Taber, C. R. (1982). The Theory and Practice of Translation. E.J. Brill.

[12] Rani. (2018). Penggunaan Majas Sindiran dalam Pembelajaran Bahasa Indonesia Siswa kelas IX SMPN 1 Balaesang Desa Tambu Kecamatan Balaesang Kabupaten Donggala. Jurnal Bahasa dan Sastra 3(4).

[13]Toer, Pramoedya A. (2011). Bumi Manusia. Lentera Dipantara.

[14] Toer, Pramoedya A. (1996). The Earth of Man Kind terjemahan dari Bumi Manusia penerjemah Max Lane. New York : Penguin Books.

[15] Toer, Pramoedya A. (2002). Anak Semua Bangsa. Hasta Mitra.

[16] Toer, Pramoedya A. (1996). Child of All Nations terjemahan dari Anak Semua Bangsa penerjemah Max Lane. Penguin Books. 